Article

\title{
Modeling of $\mathrm{H}_{2} \mathrm{~S}$ Dispersion in Brazil with Aermod: Case Study of Water Resource Recovery Facility In South of Brazil
}

\author{
Matheus Ribeiro Augusto $^{1}$ (D), Bruno Campos $^{1}$ (D), Vanessa Silveira Barreto Carvalho ${ }^{1}$ (D), \\ Herlane Costa Calheiros ${ }^{1}$ \\ ${ }^{1}$ Instituto de Recursos Naturais, Universidade Federal de Itajubá, Itajubá, MG, Brazil.
}

Received: 15 January 2019 - Accepted: 12 March 2019

\begin{abstract}
Water Resource Recovery Facility (WRRF) can be source of odorous gases. We analyzed the emission and dispersion of hydrogen sulfide gas $\left(\mathrm{H}_{2} \mathrm{~S}\right)$, odor indicator, produced during the anaerobic treatment of wastewaters, using WATER9 and AERMOD models for two distinct events: August 2013 and February-March 2014. Data from two WRRF in Brazil were used to feed the model and a statistical data validation was performed, followed by an evaluation of model results regarding $\mathrm{H}_{2} \mathrm{~S}$ emission and dispersion. Daily peak events and averages over the two periods were calculated. Results show a good performance from the model in comparison to the observations. Moreover, odor plumes typically reached 2-4 km from their sources and they may be strongly affected by atmospheric stability/instability conditions in the events analyzed and, in general, only the residences at the vicinity of WRRF were affected by the pollutant odor. Finally, the methodology presented showed to be feasible and realistic for purposes of WRRF planning and management.
\end{abstract}

Keywords: $\mathrm{H}_{2} \mathrm{~S}$, hydrogen sulfide, odor plume, sewer system, numerical modeling.

\section{Modelagem da Dispersão de $\mathrm{H}_{2} \mathrm{~S}$ no Brasil com Aermod: Estudo de Caso em Estação de Recuperação de Recursos Hídricos no Sul do Brasil}

\begin{abstract}
Resumo
Estação de Recuperação de Recursos Hídricos (ERRH) pode ser fonte de gases odoríferos. Analisamos a emissão e dispersão do gás sulfídrico $\left(\mathrm{H}_{2} \mathrm{~S}\right)$, indicador de odor, produzido durante o tratamento anaeróbio de águas residuárias, utilizando os modelos WATER9 e AERMOD para dois eventos distintos: Agosto 2013 e Fevereiro-Março 2014. Os dados de duas ERRH no Brasil foram utilizados para alimentar o modelo e uma validação de dados estatísticos foi realizada, seguida de uma avaliação dos resultados do modelo em relação à emissão e dispersão de $\mathrm{H}_{2} \mathrm{~S}$. Picos diários e médias dos dois períodos foram calculados. Os resultados mostram um bom desempenho do modelo em comparação com as observações. Além disso, as plumas odoríferas tipicamente atingem 2-4 km de suas fontes e podem ser fortemente afetadas pelas condições de estabilidade / instabilidade atmosférica nos eventos analisados e, em geral, apenas as residências nas proximidades de ERRH foram afetadas pelo odor poluente. Por fim, a metodologia apresentada mostrou-se viável e realista para fins de planejamento e gestão de ERRH.
\end{abstract}

Palavras-chave: $\mathrm{H}_{2} \mathrm{~S}$, sulfeto de hidrogênio, pluma de odor, rede de esgoto, modelagem numérica.

\section{Introduction}

The anaerobic treatment of sanitary and industrial wastewater using high-rate anaerobic reactors type UASB (Upflow Anaerobic Sludge Blanket) is broadly used in Brazil and also worldwide, mostly because of its economic advantages in comparison to purely aerobic systems.
However, the anaerobic digestion of organic matter may follow a sulfidogenic pathway, where the sulfate $\left(\mathrm{SO}_{4}{ }^{2-}\right)$ is reduced to hydrogen sulfide $\left(\mathrm{H}_{2} \mathrm{~S}\right)$ : a highly toxic gas with foul odor. This compound can be often found at considerable concentrations at the vicinity of Water Resource

Corresponding author: Herlane Costa Calheiros, h2c@unifei.edu.br. 
Recovery Facility (WRRF) (Chernicharo, 2007; Tchobanoglous et al., 2013).

According to the World Health Organization (WHO, 2000) the presence of $\mathrm{H}_{2} \mathrm{~S}$ in the atmosphere with concentrations over $15 \mathrm{mg} \cdot \mathrm{m}^{-3}$ can cause adverse effects to human health, from simple respiratory problems to lethal complications when exposing individuals to concentrations over $1400 \mathrm{mg} \cdot \mathrm{m}^{-3}$. Regarding odor, $\mathrm{H}_{2} \mathrm{~S}$ can cause discomfort at low concentrations (about $0.7 \mu \mathrm{g} \cdot \mathrm{m}^{-3}$ ), equivalent to $0.00047 \mathrm{ppm}$ at $25{ }^{\circ} \mathrm{C}$ and $1 \mathrm{~atm}$ (Tchobanoglous et al., 2013). Therefore, an appropriate handling of this compound is crucial to minimize the impacts to the neighborhood of WRRF. Grasel (2014) performed a $\mathrm{H}_{2} \mathrm{~S}$ concentration monitoring around two WRRF in Brazil; the research shows pollutant concentrations over the olfactory perception threshold in several locations, placing those treatment plants as sources of odorous gases in that area. Significant levels of $\mathrm{H}_{2} \mathrm{~S}$ can be usually found in a WRRF during the preliminary treatment (solid retention) and during the sludge treatment process. Still, the secondary treatment in anaerobic reactors keeps the main source of emission (Chernicharo et al., 2015).

Mathematical models for emission and dispersion of atmospheric pollutants can assist agencies on the management of $\mathrm{H}_{2} \mathrm{~S}$. The mechanism of pollutant removal that prevails in this situation is the volatilization from quiescent surfaces. Such mechanism depends on the compound's mass transfer coefficients in the liquid and gas phases $\left(\mathrm{k}_{\mathrm{L}}\right.$ e $\mathrm{k}_{\mathrm{G}}$, respectively) and, consequently, on the global mass transfer coefficient (K). The WATER9 model proposed by the United States Environmental Protection Agency (USEPA, 1994) has been substantially used and it has produced good results in studies of odorous gases emission in WRRF (Santos et al., 2006; Santos et al., 2012). Sá (2011) used several models to estimate $\mathrm{H}_{2} \mathrm{~S}$ emissions in a UASB reactor; results show that values modeled with WATER9 were the closest to observations.

Atmospheric dispersion modeling is used to assess the $\mathrm{H}_{2} \mathrm{~S}$ behavior in the atmosphere and hence, its range of impact. The influence of atmospheric stability as well as the climate and geophysical conditions (orography and landuse) can be assessed from the pollution dispersion patterns (Sironi et al., 2010; Latos et al., 2011; O'Shaughnessy and Altmaier, 2011; Melo et al., 2012; Olafsdottir et al., 2014; Abdul-Wahab et al., 2014; Augusto et al., 2017).

Latos et al. (2011) and Abdul-Wahab et al. (2014) found, via AERMOD and CALPUFF models, that higher atmospheric stability leads to higher $\mathrm{H}_{2} \mathrm{~S}$ concentrations at the source's surroundings. The turbulence (mechanical and convective) and, consequently, the pollutant transport are hampered in this situation. Olafsdottir et al. (2014), using AERMOD, studied the influence of terrain features on the pollutant dispersion, since mountain-chains tend to confine and guide plumes, mainly during strong atmo- spheric stability. Augusto et al. (2017) analyzed the dispersion of $\mathrm{H}_{2} \mathrm{~S}$ from an anaerobic unit of wastewater treatment located in a rural district of the city of Itajubá (MG), Brazil. For this, a Gaussian model AERMOD was applied using actual pollutant emission rate data in the UASB reactor, as well as meteorological and geophysical information (topography and land use). Using simulations, it was found that the odor plume was oriented by relief and concentrated near the treatment unit, limiting the impact to the rural district. Models with sulfate reduction for a very high strength and sulfate rich wastewater have been used to assess the anaerobic digestion of cane-molasses vinasse (Barrera et al., 2015). Moreover, the biogas from anaerobic wastewater treatment plants in Brazil was studied to assess the feasibility and potential of power production (Santos et al., 2016).

Emission and dispersion models for $\mathrm{H}_{2} \mathrm{~S}$ only were used but less commonly. Thus, studies with different models to analyze this pollutant distribution around a WRRF are fundamental. Such researches verify their accuracy and the feasibility of methodologies. However, limitations exist: according to Holmes and Morawska (2006) and Chapela et al. (2014) "peaks" of atmospheric emissions (on topic $\mathrm{H}_{2} \mathrm{~S}$ ) may be smoothened since AERMOD uses hourly averages instead of smaller steps to calculate timeseries. USEPA considers AERMOD as a regulatory model and suggests its application on studies with radius of influence lesser than $50 \mathrm{~km}$ (Rood, 2014).

Therefore, this research aims to analyze the emission and dispersion of $\mathrm{H}_{2} \mathrm{~S}$ from the anaerobic treatment of wastewaters, using WATER9 and AERMOD models. The model accuracy on predicting the pollutant concentrations at distinct points is also assessed. Thereunto, two WRRF Brazil will be investigated.

\section{Data and Methodology}

\subsection{Study area and emission estimates}

We studied two wastewater treatment plants $\left(\mathrm{WRRF}_{\mathrm{A}}\right.$ and $\left.\mathrm{WRRF}_{\mathrm{B}}\right)$ located in South of Brazil. The secondary treatment in both WRRF is performed in anaerobic reactors type $U A S B$. $W_{R R F}\left(W_{A}\left(\mathrm{WRF}_{\mathrm{B}}\right)\right.$ has six (sixteen) reactors in parallel, processing approximately $400 \mathrm{~L} \cdot \mathrm{s}^{-1}\left(1100 \mathrm{~L} \cdot \mathrm{s}^{-1}\right)$.

$\mathrm{H}_{2} \mathrm{~S}$ emission rates were estimated using WATER9. We considered emissions from the surface of decanters as the main source of pollution, since the gas collected into the three-phase separators was burnt and/or treated prior releasing. Data necessary for this stage consist of: $\mathrm{H}_{2} \mathrm{~S}$ concentration for liquid phase, affluent temperature, $\mathrm{pH}$, sewage flow rate, meteorological data (wind speed and air temperature) and plant unit dimensions (pitch diameter and depth). These data were provided by a sewer system operator in Brazil. Since this research may produce poten- 
tially sensitive results, the data utilized were provided by our source following a confidentiality agreement; hence, the identity of our data provider and local of study were not disclosed in order to protect its integrity.

Finally, meteorological data were collected at the INFRAERO aeronautical meteorology service data platform and retrieved by the Center for Weather Forecasting and Climate Studies (CPTEC/INPE; bancodedados.cptec. inpe.br/downloadBDM/).

\subsection{Numerical models}

Gaussian model AERMOD was used to assess the pollutant dispersion in the atmosphere. AERMOD is proposed by USEPA (2004) and developed by AERMIC (AMS/EPA Regulatory Model Improvement Committee). The simulation with AERMOD consists of main module AERMOD and two pre-processors: meteorological (AERMET) and geographical (AERMAP). One simulation with Cartesian grid was performed for each WRRF, centered at their coordinates, both with $500 \mathrm{~m}$ of spatial resolution, covering a radius of $15 \mathrm{~km}$ with $61 \times 61$ receptors. Data were obtained for two periods: August 2013; February/ March 2014.

AERMET entering meteorological data collected from the local airport, located $16 \mathrm{~km}(6 \mathrm{~km})$ from $\mathrm{WRRF}_{\mathrm{A}}$ $\left(\mathrm{WRRF}_{\mathrm{B}}\right)$. Hourly data were obtained from CPTEC/INPE databases. High-altitude data were obtained from NOAA/ ESRL databases (esrl.noaa.gov/raobs/). Since WRRF are located inside a predominantly urban area, typical surface parameters in the models are related to such landuse, according to USEPA (2013) guidelines. AERMAP entering ASTGTM GDEM terrain data from the United States Geological Survey (USGS; http://earthexplorer.usgs.gov) with 30 meters of horizontal resolution.

Finally, module AERMOD, in addition to data generated during the pre-processing stage, required information related to the sources: emission rate $\left(\mathrm{g} \cdot \mathrm{s}^{-1} \cdot \mathrm{m}^{-2}\right)$, plume height and source's area. Emission rates were calculated with WATER9, as described previously.

\subsection{Results verification}

To assess the quality of data outputted from AERMOD, a data comparison was performed using the statistical parameters recommended by Hanna et al. (1991; 1993 ) and Chang and Hanna (2004): fractional bias (FB), normalized mean square error (NMSE), correlation coefficient $(R)$, geometric mean bias $(M G)$, geometric variance $(V G)$ and fraction of predictions within a factor of two of observations (FAC2). Many other related studies also applied a similar methodology (Hanna et al., 2004; Mohan et al., 2011; Rood, 2014; Gulia et al., 2015). Results were then compared with $\mathrm{H}_{2} \mathrm{~S}$ values measured in twelve different points around the $\mathrm{WRRF}_{\mathrm{A}}$ by Grasel (2014), in August 2013 (austral winter); February/March 2014 (austral summer), totaling 36 samples. $\mathrm{H}_{2} \mathrm{~S}$ was collected using pas- sive samplers of the Radiello® brand. In these samplers, $\mathrm{H}_{2} \mathrm{~S}$ is chemically adsorbed by zinc acetate and converted to stable zinc sulfide for further extraction and spectrophotometric analysis (methylene blue method). The statistical parameters are presented in Eqs. (1)-(6):

$$
\begin{gathered}
F B=\frac{\left(\overline{C_{o}}-\overline{C_{p}}\right)}{\left.0.5 \overline{\left(C_{o}\right.}+\overline{C_{p}}\right)} \\
N M S E=\frac{\overline{\left(C_{0}-C_{p}\right)}}{\overline{C_{0} C_{p}}} \\
R=\frac{\left(\overline{\left.C_{o}-\overline{C_{o}}\right)\left(C_{p}-\overline{C_{p}}\right)}\right.}{\sigma_{C_{p}} \sigma_{C_{o}}} \\
M G=\exp \left(\overline{\ln C_{o}}-\overline{\ln C_{p}}\right) \\
V G=\exp \left[\overline{\left(\ln C_{o}-\ln C_{p}\right)^{2}}\right] \\
F A C 2=\text { fraction of data that satisfy :0.5 } \leq \frac{C_{p}}{C_{o}} \leq 2.0
\end{gathered}
$$

where $C_{p}$ is the AERMOD predictions, $C_{o}$ is the average over observations, $\overline{C_{p}}$ is the average over predictions, and $\sigma$ the standard deviation over the dataset. This methodology assumes that mean bias is within $\pm 30 \%$ of the mean (i.e., roughly $|F B|<0.3$ or $0.7<M G<1.3$ ). The random scatter is about a factor of two to three of the mean (i.e., roughly $N M S E<1.5$ or $V G<4.0$ ). The fraction of predictions within a factor of two of observations is about $50 \%$ or greater (i.e., FAC2 > 0.5).

\subsection{Events}

Emission and dispersion simulations for $\mathrm{WRRF}_{\mathrm{A}}$ and $\mathrm{WRRF}_{\mathrm{B}}$ were performed in August 2013 (austral winter); February/March 2014 (austral summer), the same time period used in data validation. Dispersion maps were plotted for the greatest daily mean (critical scenario) and average over period (mean scenario), for both WRRF. Values were calculated in $\mu \mathrm{g} \cdot \mathrm{m}^{-3}$ and show distinct thresholds: $0.7 \mu \mathrm{g} \cdot \mathrm{m}^{-3}$ is the odor detection threshold (Tchobanoglous et al., 2013); and $2.0 \mu \mathrm{g} \cdot \mathrm{m}^{-3}$ is the Inhalation Reference Concentration (RfC), the limit of adverse effects to human health (USEPA, 2003).

\section{Results and Discussion}

\subsection{Data validation}

Results from data validation are presented in Table 1. According to the statistics, the methodology proposed is valid to study $\mathrm{H}_{2} \mathrm{~S}$ : the parameters lay within the 
Table 1 - Statistical parameters from the data comparison.

\begin{tabular}{lccc}
\hline Parameter & WRRF $_{\mathrm{A}}$ & Ideal fit & Validation limits \\
\hline$F B$ & 0.078 & 0 & $-0.3 \leq F B \leq 0.3$ \\
$N M S E$ & 0.63 & 0 & $\leq 1.5$ \\
$R$ & 0.65 & 1 & close to 1 \\
$M G$ & 0.85 & 1 & $0.7 \leq M G \leq 1.3$ \\
$V G$ & 4.79 & 1 & $\leq 4.0$ \\
$F A C 2(\%)$ & 53 & 100 & $\geq 0.5$ \\
\hline
\end{tabular}

limits, except for $V G$. Moreover, since $F A C 2=53 \%$ and the dataset variance is not great, the linear parameters have a better fit when comparing the dispersion model to observations.

Parameter $F B$ shows a positive sign, close to ideal and within limits. Its value indicates a light overestimation of $\mathrm{H}_{2} \mathrm{~S}$ concentrations by AERMOD. NMSE is also within validation limits. Correlation coefficient $(R)$ does not indicate a strong correlation between modeled and observed data. However, a linear relation between both exists, is directly proportional and has statistical significance at a $95 \%$ confidence level $(p=0.05) . M G$ stays within acceptable limits, considering 30\% error margin around ideal values.

The $\mathrm{FAC} 2=53 \%$ shows that $53 \%$ of the data are within interval $0.5 \leq \frac{\mathrm{C}_{\mathrm{p}}}{\mathrm{C}_{\mathrm{o}}} \leq 2.0$ (Fig. 1), a satisfactory result. Since $F A C 2$ is a robust tool, this parameter is important on models' evaluation and validation as it is not deeply affected by outliers. Such results are very satisfactory due to limitations and simplifications in numerical models. AERMOD solves plumes as stationary in the hourly averages, hence some "peak events" may be

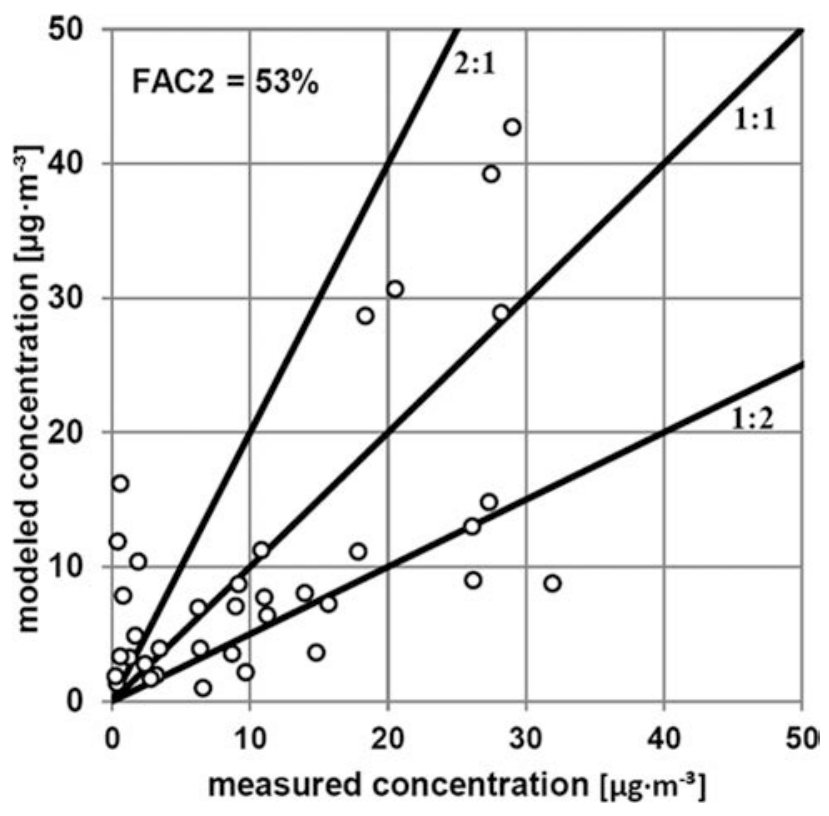

Figure 1 - Measured $\mathrm{H}_{2} \mathrm{~S}$ (x-axis) and modeled data (y-axis). smoothened; the complex terrain module is simplified and the modules do not solve wet and dry deposition as well as chemical reactions, responsible for secondary pollutants.

\section{2. $\mathrm{H}_{2} \mathrm{~S}$ dispersion simulations}

Figure 2 shows $\mathrm{H}_{2} \mathrm{~S}$ dispersion plumes from $\mathrm{WRRF}_{\mathrm{A}}$ for the greatest daily mean of (Fig. 2a) August 2013 and (Fig. 2b) February/March 2014 ; and average over (Fig. 2c) August 2013 and average over (Fig. 2d) February/March 2014. In August 2013, the odor plume (regions with concentrations around $0.7 \mu \mathrm{g} \cdot \mathrm{m}^{-3}$ ), reached roughly $4 \mathrm{~km}$ from its source at some areas in the east $\left(270^{\circ}\right)$, west-northwest $\left(292.5^{\circ}\right)$, southwest $\left(225^{\circ}\right)$ and south $\left(180^{\circ}\right)$ directions, as presented in Fig. 2a. On February and March 2014 (Fig. 2b) the greatest daily means showed a range of around $3.5 \mathrm{~km}$ in the southeast $\left(135^{\circ}\right)$, south-southwest $\left(202.5^{\circ}\right)$, southwest $\left(225^{\circ}\right)$ and westsouthwest $\left(247.5^{\circ}\right)$ directions. In the north-northeast $\left(22.5^{\circ}\right)$ and west-northwest $\left(292.5^{\circ}\right)$ directions, the plume reached approximately $2 \mathrm{~km}$ from its source. This $\mathrm{H}_{2} \mathrm{~S}$ dispersion in the atmosphere occurred in a relatively homogeneous way and may be associated with low-intensity winds.

The meteorological conditions on the period (austral summer) tend to ease the vertical dispersion of pollutants due to stronger convective air mass fluxes (thermal turbulence). Thus, the $\mathrm{H}_{2} \mathrm{~S}$ dispersion (range) can be lesser. However, we lack data to infer the influence of thermally and mechanically produced turbulence on the $\mathrm{H}_{2} \mathrm{~S}$ dispersion, as well as the differences found between these periods. Furthermore, we cannot assure that all residences within the area inside the $0.7 \mu \mathrm{g} \cdot \mathrm{m}^{-3}$ polygon were affected by the odorous gas. The odor detection threshold is unique among individuals and it varies, for $\mathrm{H}_{2} \mathrm{~S}$, from 0.7 to $14.0 \mu \mathrm{g} \cdot \mathrm{m}^{-3}$ (Ruth, 1986). Still in Figures 2a and 2b, the polygon related to $\mathrm{RfC}\left(2.0 \mu \mathrm{g} \cdot \mathrm{m}^{-3}\right)$ reaches roughly $2 \mathrm{~km}$ southwestward $\left(225^{\circ}\right)$ and $1.6 \mathrm{~km}$ south-southwestward $\left(202.5^{\circ}\right)$.

Figures $2 \mathrm{c}$ and $2 \mathrm{~d}$ show the average dispersion of $\mathrm{H}_{2} \mathrm{~S}$ at $\mathrm{WRRF}_{\mathrm{A}}$ over the period August 2013 and February/March 2014, respectively. Only the residences at the vicinity of $\mathrm{WRRF}_{\mathrm{A}}$ were affected by the pollutant odor. However, such average over time smoothes peak events when odor plumes happen to reach broader areas. In August 2013 (Fig. 2c) the odor plume was displaced southwestward $\left(225^{\circ}\right)$, reaching up to $950 \mathrm{~m}$ from the source. In February/March 2014 (Fig. 2d) it reached up to $550 \mathrm{~m}$ southwestward.

The odor plume for $\mathrm{WRRF}_{\mathrm{B}}$ shows a maximum range of $11.5 \mathrm{~km}$ northwestward (approximately $303^{\circ}$ ) for the greatest daily mean in August 2013 (Fig. 3a). For the west $\left(270^{\circ}\right)$ and southwest $\left(225^{\circ}\right)$ directions, it showed a range of around $9 \mathrm{~km}$, followed by $5 \mathrm{~km}$ south $\left(180^{\circ}\right)$ and north-northeast $\left(22.5^{\circ}\right)$. In February/March 2014 (Fig. 3b) 

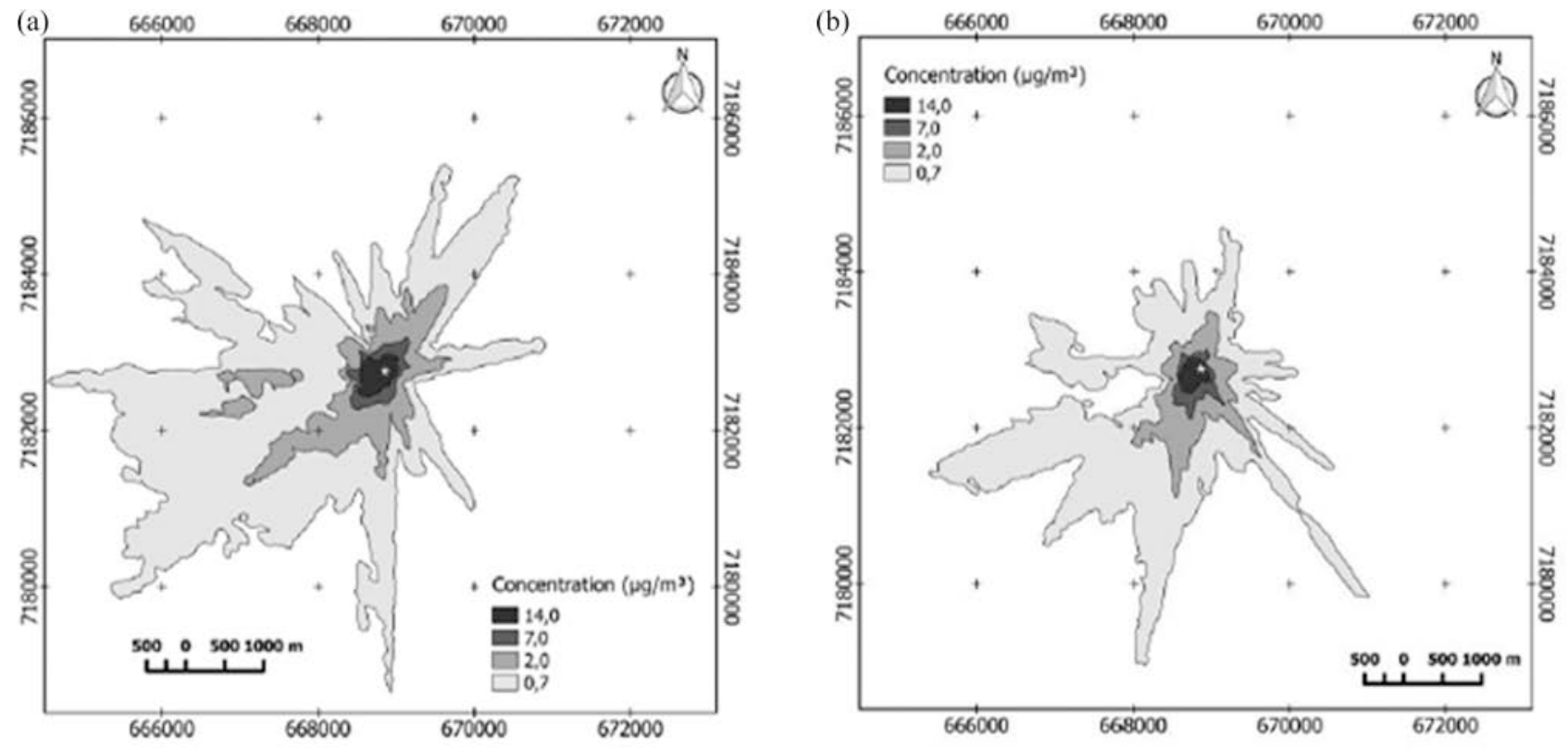

(c)

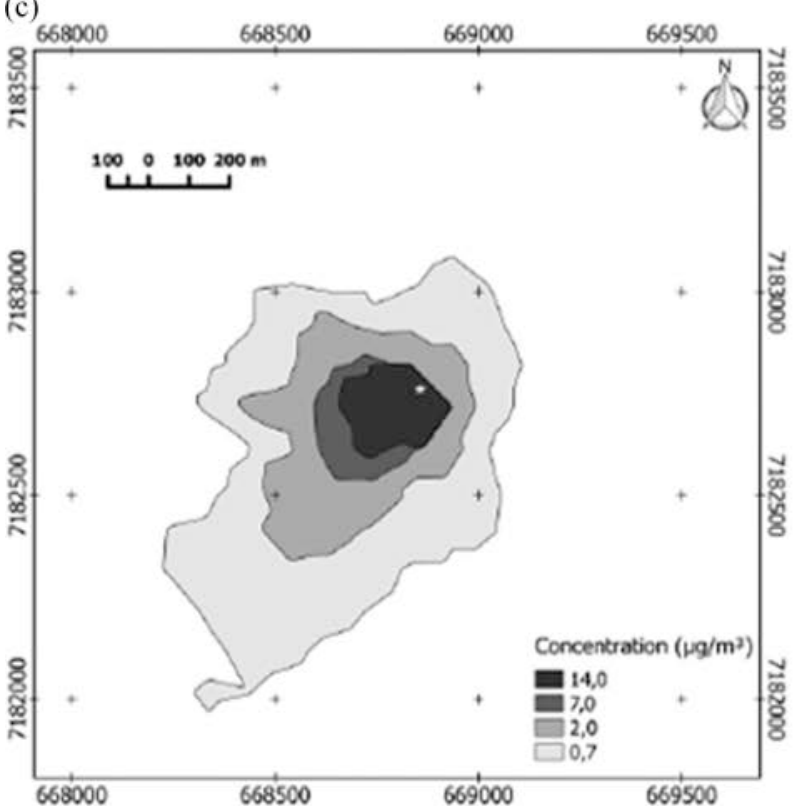

(d)

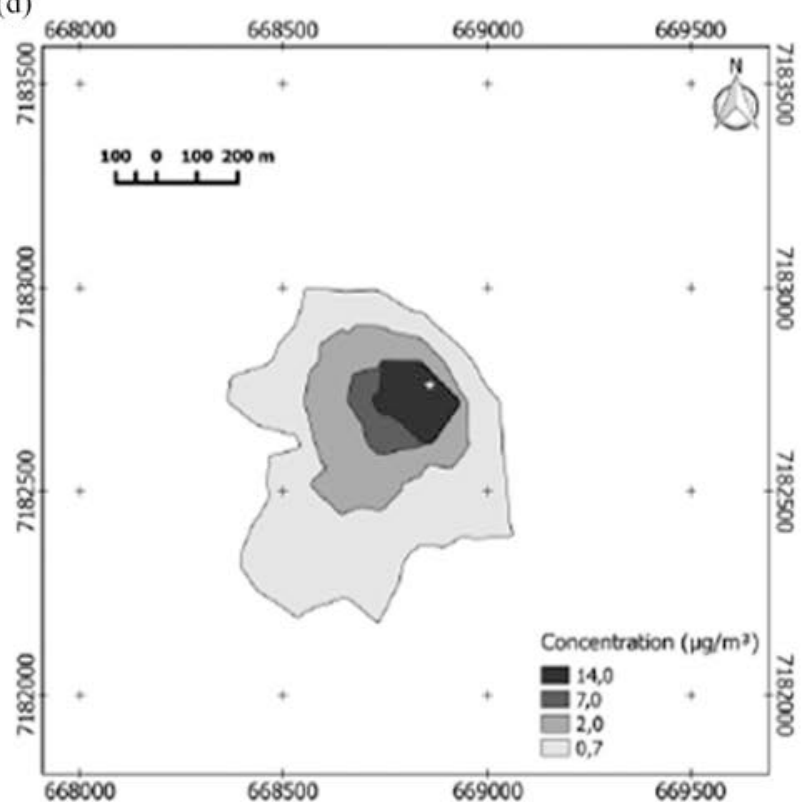

Figure $2-\mathrm{H}_{2} \mathrm{~S}$ dispersion plumes for $\mathrm{WRRF}_{\mathrm{A}}$. Greatest daily mean of (a) August 2013 and (b) February/March 2014. Average over (c) August 2013 and average over (d) February/March 2014.

the plume presented a maximum range of $7 \mathrm{~km}$ westsouthwestward $\left(247.5^{\circ}\right)$ and southeastward $\left(144^{\circ}\right)$.

During the same period analyzed, odor plumes of greatest daily averages from the $\mathrm{WRRF}_{\mathrm{A}}$ (Figs. 2a-2b) showed a narrower range in comparison to $\mathrm{WRRF}_{\mathrm{B}}$. Such difference between them is related mostly due to the size of the units. $\mathrm{WRRF}_{\mathrm{A}}$ has $6 \mathrm{UASB}$ cells with $2,000 \mathrm{~m}^{3}$ each, and $\mathrm{WRRF}_{\mathrm{B}}$ has $16 \mathrm{UASB}$ cells with the same dimensions. Thus, $\mathrm{WRRF}_{\mathrm{B}}$ has a capacity of around $1,120 \mathrm{~L} \cdot \mathrm{s}^{-1}$ while
$\mathrm{WRRF}_{\mathrm{A}}$ treats $400 \mathrm{~L} \cdot \mathrm{s}^{-1}$ on average. Such differences also impact the emission rates on each plant.

For the greatest daily averages in August 2013 (Fig. 3a), we also plotted the polygon with $150 \mu \mathrm{g} \cdot \mathrm{m}^{-3}$ threshold, in reference to the limit of chronic exposure to $\mathrm{H}_{2} \mathrm{~S}$ established by the WHO (2000). The area shows a maximum range of $400 \mathrm{~m}$ westward $\left(270^{\circ}\right)$, only at the vicinity of the plant. In February/March 2014 (Fig. 3b), none of the records surpassed $150 \mu \mathrm{g} \cdot \mathrm{m}^{-3}$. 
(a)

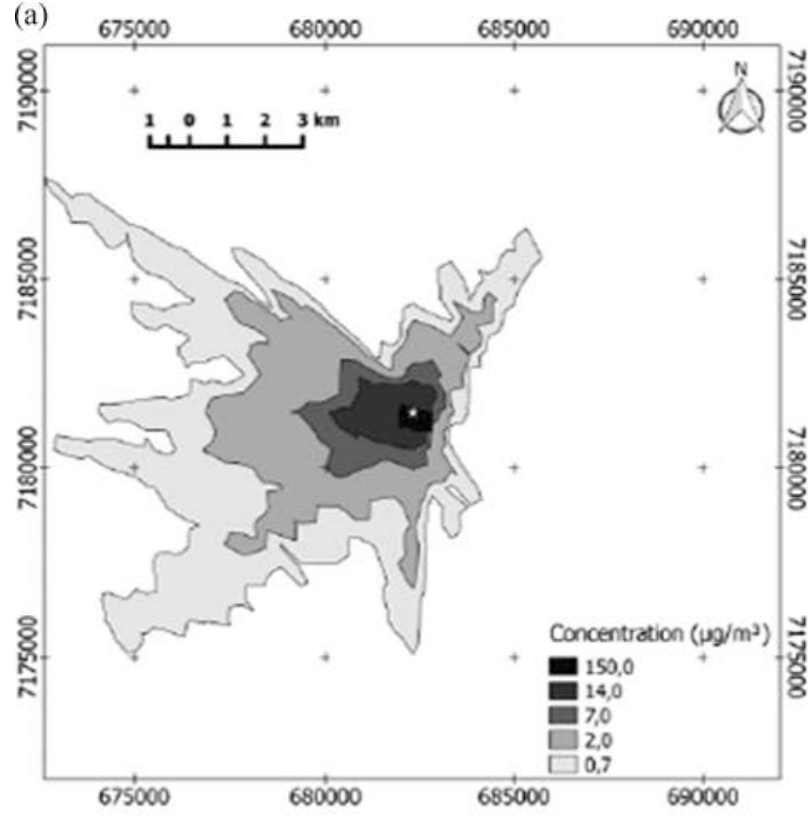

(c)

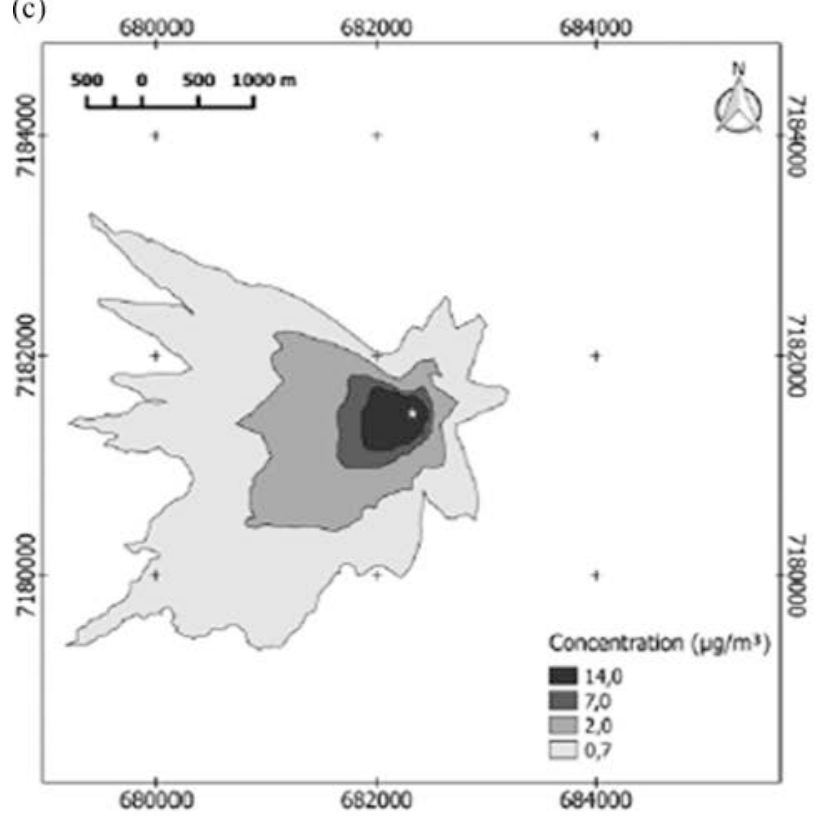

(b)

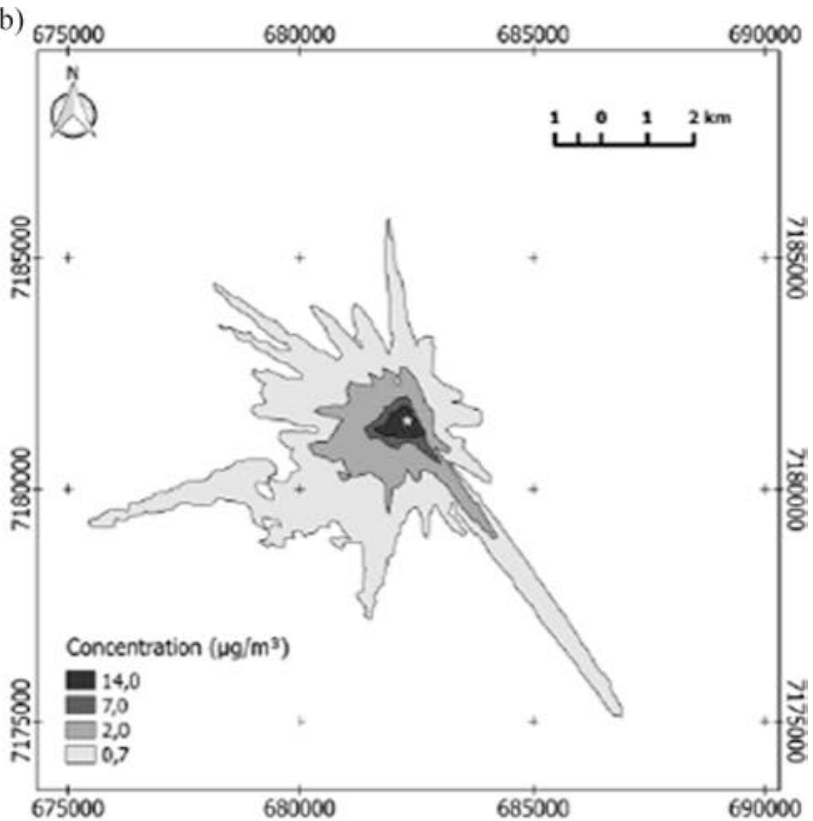

(d)

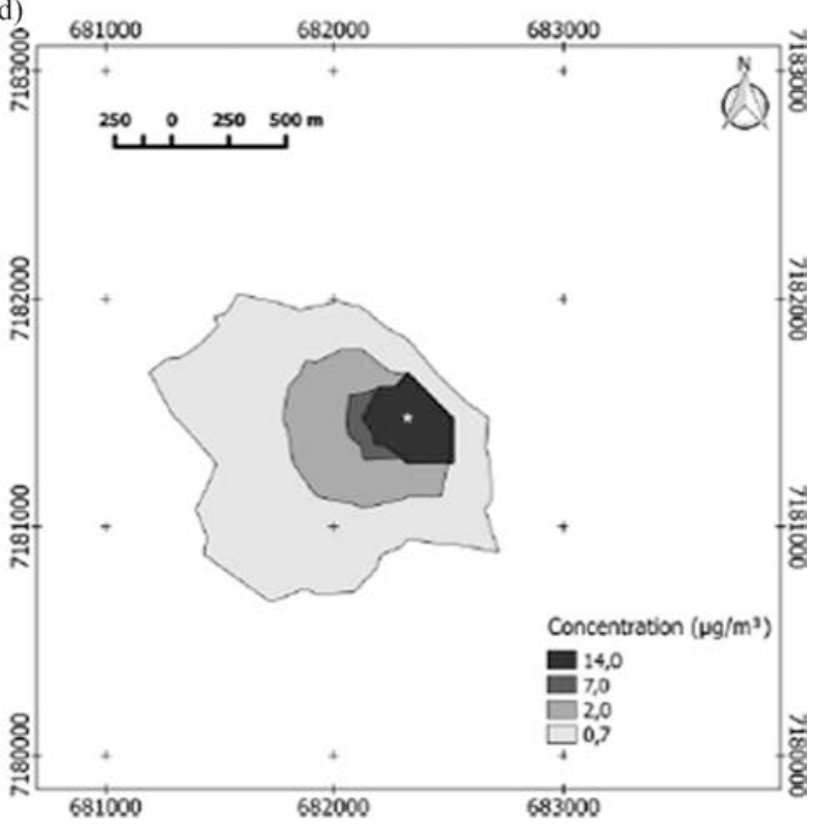

Figure $3-\mathrm{H}_{2} \mathrm{~S}$ dispersion plumes for $\mathrm{WRRF}_{\mathrm{B}}$. Greatest daily mean of (a) August 2013 and (b) February/March 2014. Average over (c) August 2013 and average over (d) February/March 2014.

Figures $3 \mathrm{c}$ and $3 \mathrm{~d}$ show the average pollutant dispersion from $\mathrm{WRRF}_{\mathrm{B}}$ over August and February/March 2014, respectively. The $\mathrm{WRRF}_{\mathrm{B}}$ presented an average emission rate of $1.14 \mathrm{~g} \cdot \mathrm{s}^{-1}$; however, over August 2013 the average dispersion of the odor plume showed a large coverage and was not limited to the very neighborhood of the plant, showing the effect of local topography on wind flow that facilitated dispersion of pollutants. The reference thresholds for chronic and acute exposition were not found around $\mathrm{WRRF}_{\mathrm{B}}$, considering the average of the periods. Yet the perception of the odor can occur in only a few seconds, that is, the mean values predicted by the model tend to ignore peak odor events. But, it can be corrected through the peak-to-mean ratio (LATOS et al., 2011).

In general, both WRRF in both periods show a direct relation between wind directions and plumes' dispersion/ orientation, since the dispersion of odorous plumes for the average over the period matches the resultant wind fields. The same pattern was found by other authors studying 
$\mathrm{H}_{2} \mathrm{~S}$ (O'Shaughnessy and Altmaier, 2011; Olafsdottir and Gardarsson, 2013; Abdul-Wahab et al., 2014). Thus, the analysis of model results and variables important to dispersion (wind temperature and relief) can provide useful information for decision makers and for the gas handling. It is possible to investigate which residences would be more affected by the gas and, hence, guide the impact's mitigation. Future projects can verify numerous $\mathrm{H}_{2} \mathrm{~S}$ emission and dispersion cases in order to predict their impacts beforehand. Such methodology makes possible to determine the more appropriate areas to implement WRRF. It should consider, besides technical (area, proximity to receptor bodies, urban layout, etc.) and economical requirements, the emission and dispersion of odorous gases and the adequate distance to houses (Chernicharo, 2007).

AERMOD is also able to assess the impacts of orography (terrain) on the pollutant dispersion. However, since both WRRF are located in a flat area (heights from 870 to $1003 \mathrm{~m}$ ), the influence of orography is strongly suppressed (Olafsdottir et al., 2014; Abdul-Wahab et al., 2014).

\section{Conclusion}

The presence of $\mathrm{H}_{2} \mathrm{~S}$ in the atmosphere can cause adverse effects to human health and discomfort due to odor. Thus, the atmospheric dispersion modeling is a tool that can help scientists and decision makers to assess its emissions, to handle and to manage human and financial resources potentially vulnerable to the emission generated by wastewater treatment plants.

We conclude that the methodology here applied was effective to assess $\mathrm{H}_{2} \mathrm{~S}$ emissions and dispersion: simulations conducted using AERMOD were feasible when comparing observed data and its statistics. Odor plumes typically reached over $2-4 \mathrm{~km}$ from their sources and they may be strongly affected by atmospheric stability/instability conditions for the events analyzed. Moreover, areas at the vicinity of the WRRF were affected by levels of $\mathrm{H}_{2} \mathrm{~S}$ that may cause health problems to individuals, in addition to odor discomfort and other mild outcomes. When the relief is flat, there is the predominant influence of the winds in the dispersion of the odor plume.

The control and handling of $\mathrm{H}_{2} \mathrm{~S}$ is feasible; however, the methods often demand high investments but are necessary due to pressures from society and environmental agencies. Preventive measures, such as the installation of WRRF with sufficient distance from residences, can minimize the impacts of odor discomfort and can be adopted in future developments. The methodology here exposed seems feasible and realistic for purposes of planning and management, as verified from the results of the cases here presented.

\section{Acknowledgments}

This research received funding from the Coordination for the Improvement of Higher Education Personnel (CAPES).

\section{References}

ABDUL-WAHAB, S.A.; CHAN, K.; ELKAMEL, A.; AHMADI, L. Effects of meteorological conditions on the concentration and dispersion of an accidental release of $\mathrm{H} 2 \mathrm{~S}$ in Canada. Atmospheric Environment, v. 82, p. 316-326, 2014.

AUGUSTO, MATHEUS RIBEIRO; CALHEIROS, HERLANE COSTA; CARVALHO, VANESSA SILVEIRA BARRETO. Simulação numérica da dispersão do sulfeto de hidrogênio emitido por um reator UASB para tratamento de esgoto doméstico. Rev. Ambient. Água, v. 12, n. 2, p. 215 $225,2017$.

BARRERA, E.L.; SPANJERS, H.; SOLON, K.; AMERLINCK, Y.; NOPENS, I.; DEWULF, J. Modeling the anaerobic digestion of cane-molasses vinasse: Extension of the Anaerobic Digestion Model No. 1 (ADM1) with sulfate reduction for a very high strength and sulfate rich wastewater. Water Research, v. 71, p. 42-54, 2015.

CHANG, J.C.; HANNA, S.R.; Air quality model performance evaluation. Meteorology and Atmospheric Physics, v. 87, p. 167-196, 2004.

CHAPELA, F.C.; BRAVO, A.D.; SOUTO, J.A.; FILIPPI, G.R. Modeling the Odor Generation in WWTP: An Integrated Approach Review. Water, Air, \& Soil Pollution, v. 225, n. 6, p. $1-15,2014$.

CHERNICHARO, C.A.L. Anaerobic Reactors, 1. ed., London: IWA Publishing, pp. 175, 2007.

CHERNICHARO, C.A.L.; VAN LIER, J.B.; NOYOLA, A.; RIBEIRO, T.B. Anaerobic sewage treatment: state of the art, constraints and challenges. Reviews in Environmental Science and Bio/Technology, v. 14, n. 4, p. 649-679, 2015.

GRASEL, A.M. Determinação de sulfeto de hidrogênio nas proximidades de estações de tratamento de esgoto $\mathrm{em}$ Curitiba - PR, Brasil. Master's Degre Dissertation, Universidade Federal do Paraná, 2014.

GULIA, S.; KUMAR, A.; KHARE, M. Performance evaluation of CALPUFF and AERMOD dispersion models for air quality assessment of an industrial complex. Journal of Scientific and Industrial Research, v. 74, p. 302-307, 2015.

HANNA, S.R.; STRIMAITIS, D.G.; CHANG, J.C. Hazard response modeling uncertainty (a quantitative method), Vol. I: User's guide for software for evaluating hazardous gas dispersion models; Vol. II: Evaluation of commonly-used hazardous gas dispersion models, Vol. III: Components of uncertainty in hazardous gas dispersion models. Final report, Washington D.C., OIST, 1991.

HANNA, S.R.; CHANG, J.C.; STRIMAITIS, D.G. Hazardous gas model evaluation with field observations. Atmospheric Environment, v. 27A, p. 2265-2285, 1993.

HANNA, S.R.; HANSEN, O.R.; DHARMAVARAM, S. FLACS CFD air quality model performance evaluation with Kit 
Fox, MUST, Prairie Grass, and Emu observations. Atmospheric Environment, v. 38, n. 28, p. 4675-4687, 2004.

HOLMES, N.S.; MORAWSKA, L.A. Review of dispersion modelling and its application to the dispersion of particles: An overview of different dispersion models available. Atmospheric Environment, v. 40, n. 30, p. 5902-5928, 2006.

LATOS, M.; KARAGEORGOS, P.; KALOGERAKIS, N.; LAZARIDIS, M. Dispersion of Odorous Gaseous Compounds Emitted from Wastewater Treatment Plants. Water, Air, and Soil Pollution, v. 215, n. 1, 667-677, 2011.

MELO, A.M.V.; SANTOS, J.M.; MAVROIDIS, I.; REIS JÚNIOR, N.C. Modelling of odour dispersion around a pig farm building complex using AERMOD and CALPUFF. Comparison with wind tunnel results. Building and Environment, v. 56, p. 8-20, 2012.

MOHAN, M.; BHATI, S.; SREENIVAS, A.; MARRAPU, P. Performance Evaluation of AERMOD and ADMS-Urban for Total Suspended Particulate Matter Concentrations in Megacity Delhi. Aerosol and Air Quality Research, v. 11, p. 883-894, 2011.

OLAFSDOTTIR, S.; GARDARSSON, S.M. Impacts of meteorological factors on hydrogen sulfide concentration downwind of geothermal power plants. Atmospheric Environment, v. 77, p. 185-192, 2013.

OLAFSDOTTIR, S.; GARDARSSON, S.M.; ANDRADOTTIR, H.O. Spatial distribution of hydrogen sulfide from two geothermal power plants in complex terrain. Atmospheric Environment, v. 82, p. 60-70, 2014.

O'SHAUGHNESSY, P.T.; ALTMAIER, R. Use of AERMOD to determine a hydrogen sulfide emission factor for swine operations by inverse modeling. Atmospheric Environment, v. 45, n. 27, p. 4617-4625, 2011.

ROOD, A.S. Performance evaluation of AERMOD, CALPUFF, and legacy air dispersion models using the Winter Validation Tracer Study dataset. Atmospheric Environment, v. 89, p. 707-720, 2014.

RUTH, J.H. Odor Thresholds and Irritation Levels of Several Chemical Substances: A Review. American Industrial Hygiene Association, v. 46, p. 142-151, 1986.

SÁ, L.M. Modelagem matemática da formação e emissão do gás sulfídrico no tratamento de esgotos domésticos. $\mathrm{PhD}$ Dissertation, Vitória, Universidade Federal do Espírito Santo, 2011.

SANTOS, J.M.; SÁ, L.M.; REIS JÚNIOR, N.C.; GONÇALVES, R.F.; SIQUEIRA, R.N. Modelling hydrogen sulphide emission in a WWTP with UASB reactor followed by aerobic biofilters. Water Science \& Technology, v. 54, n. 9, p. 173-180, 2006.

SANTOS, J.M.; KREIM, V.; JEAN-MICHEL, G.; REIS JÚNIOR, N.C.; SÁ, L.M.; HORAN, N.J. An experimental determination of the $\mathrm{H}_{2} \mathrm{~S}$ overall mass transfer coeficient from quiescent surfaces at wastewater treatment plants. Atmospheric Environment, v. 60, p. 18-24, 2012.

SANTOS, I.F.S.; BARROS, R.M.; TIAGO FILHO, G.L. Electricity generation from biogas of anaerobic wastewater treatment plants in Brazil: an assessment of feasibility and potential. Journal of Cleaner Production, v. 126, n. 10, p. 504-514, 2016.

SIRONI, S.; CAPELLI, L.; CÉNTOLA, P.; DEL ROSSO, R.; PIERUCCI, S. Odour impact assessment by means of dynamic olfactometry, dispersion modelling and social participation. Atmospheric Environment, v. 44, n. 3, p. 354360, 2010.

TCHOBANOGLOUS, G.; STENSEL, H.D.; TSUCHIHASHI, R.; BURTON, F.; ABU-ORF, M.; BOWDEN, G.; PFRANG, W. Wastewater Engineering: Treatment and Resource Recovery, 5. ed., McGraw-Hill, New York, 2013.

UNITED STATES ENVIRONMENTAL PROTECTION AGENCY - USEPA. Air Emission Models for Waste and Wastewater, Research Triangle Park, North Carolina, pp. 532, 1994.

UNITED STATES ENVIRONMENTAL PROTECTION AGENCY - USEPA. Toxicological Review of Hydrogen Sulfide, Washington DC, pp. 74, 2003.

UNITED STATES ENVIRONMENTAL PROTECTION AGENCY - USEPA. AERMOD: Description of Model Formulation, Research Triangle Park, North Carolina, pp. 91, 2004.

UNITED STATES ENVIRONMENTAL PROTECTION AGENCY - USEPA. AERSURFACE User's Guide, Research Triangle Park, North Carolina, pp. 34, 2013.

WORLD HEALTH ORGANIZATION - WHO. Air Quality Guidelines for Europe, 2.ed., Copenhagen, pp. 273, 2000.

\section{Internet Resources}

CPTEC/INPE databases. http://bancodedados.cptec.inpe.br/ downloadBDM/

License information: This is an open-access article distributed under the terms of the Creative Commons Attribution License (type CC-BY), which permits unrestricted use, distribution and reproduction in any medium, provided the original article is properly cited. 